\title{
EVALUATION OF INTER-INSTITUTIONAL COORDINATION IN DISASTER MANAGEMENT
}

Bektaş SARI ${ }^{1}$

\section{ABSTRACT}

In the environment we live in, a large number of events occur that negatively affect the lives of people and communities. These events may be caused by the environment or nature, or may be caused by people or the products or services they produce. When looking at the studies and explanations made about disasters in the historical process; First of all, the events that caused the deaths of people were treated as disasters. Later, events that cause physical or social losses, events that affect people and cause property damage, and eventually the concept of disaster; were associated with the concepts of environment, development and sustainability. The aim of this study is to; evaluates the titles and topics necessary for interagency coordination in disaster management. This study is a review article created using qualitative method. Currently, the discipline of disaster management has produced various studies in many national and international institutions. In particular, efforts to combat climate change, sustainable development goals and Disaster Risk Reduction have become central to disaster management. Incident Command System, collaboration, communication, information and resource sharing, common purpose and teamwork, flexibility and authority, and use of social media are at the heart of interagency coordination in disaster management decisively. In order for disaster and emergency situations to be managed in coordination, qualified works should be carried out in the above headings. As a result, interagency coordination in disaster management consists of the topics mentioned above.

Keywords: Coordination, Collaboration, Disaster, Disaster Management,

\section{AFET YÖNETIMMINDE KURUMLAR ARASI KOORDİNASYONUN DEĞERLENDİRILMESI}

ÖZ

Yaşadığımız çevrede insanların ve toplumların hayatını olumsuz yönde etkileyen çok sayıda olay meydana gelmektedir. Bu olaylar çevreden veya doğadan kaynaklı olabildiği gibi insanlardan veya ortaya çıkardığg ürün veya hizmetlerden kaynaklı da meydana gelebilmektedir. Tarihsel süreçte afetler ile ilgili yapılan çalışmalara ve açıklamalara bakıldığında; öncelikle insanların ölümüne sebep olan olaylar afet olarak ele alınmıştır. Daha sonra fiziksel veya sosyal kayıplar meydana getiren olaylar, insanları etkileyen

\footnotetext{
${ }^{1}$ Corresponding Authour/Sorumlu Yazar, Lecturer, Ege University, Ataturk Vocational School of Health Services, İzmir, bektas.sari@ege.edu.tr, ORCID: 0000-0002-2886-5570
} 
JPH, DECEMBER 2021, 6(3):393-406

ve maddi hasar meydana getiren olaylar ve en sonunda afet kavramı; çevre, kalkınma ve sürdürülebilirlik kavramları ile ilişkilendirilmiştir. Bu çalışmanın amacı; afet yönetiminde kurumlar arası koordinasyon için gerekli olan başlıkları ortaya koymak ve değerlendirmektedir. Bu çalışma, nitel yöntem kullanılarak oluşturulan bir derleme makale niteliğindedir. Günümüzde afet yönetimi disiplininin, birçok ulusal ve uluslararası kurum içerisinde çeşitli çalışmalar ürettiği görülmektedir. Özellikle iklim değişikliği ile mücadele, sürdürülebilir kalkınma hedefleri ve afet risk azaltımı çalışmaları, afet yönetiminin merkezinde yer alan çalışmalar haline gelmiştir. Afet yönetiminde kurumlar arası koordinasyonun temelinde; olay komuta sistemi, iş birliği, haberleşme, bilgi ve kaynak paylaşımı, ortak amaç ve takım çalışması, esneklik ve otorite ve sosyal medya kullanımı bulunmaktadır. Afet ve acil durumların, koordinasyon içerisinde yönetilebilmesi için yukarıda ki başlıklarda nitelikli çalışmalar yürütülmesi gerekmektedir. Sonuç olarak afet yönetiminde kurumlar arası koordinasyon yukarıda söz edilen başlıklardan oluşmaktadır.

Anahtar Kelimeler: Koordinasyon, İş birliği, Afet, Afet Yönetimi

\section{INTRODUCTION}

Looking at the definitions of disasters, the idea that disaster is the result, not an event itself, began to develop in the early 20th century (Carr, 1932). With these developments, the idea that disaster events occur as a result of human behaviors has started to develop. Furthermore, in the following years, it began to be stated that disasters are not natural but a result of socioeconomic events and that the concept of nature must be removed from disasters (O'Keefe et al., 1976). In the 1990s, the idea began to develop those events should have various components in order to be defined as disasters. As three components of the disaster, the World Health Organization has prepared emergency health training that addressed events that disrupt normal life, exceed capacity, and affect people (WHO, 1998). According to the definition of the United Nations (UN), which is mostly used today, disaster; is an event that exceeds the ability of the affected community or community to cope using its own resources, seriously disrupts the functioning of the community, causing widespread human, economic or environmental losses (UNISDR, 2009). Looking at the UN definitions, it is seen that disasters are now events that negatively affect all areas of human life and the environment.

Disaster management is a multifaceted, multidisciplinary and multi-actor, dynamic and complex management process that requires the use of its resources in line with the strategic objectives and priorities set out with all institutions and organizations of the society in order to plan, direct, coordinate, support and effectively implement the measures to be taken before, during and after disasters in order to prevent and reduce the damages of disasters (AFAD, 2014). Disaster management in relation to this definition; it is seen that it covers the planning, implementation and evaluation of all resources before, during and after the disaster. In addition, 
JPH, DECEMBER 2021, 6(3):393-406

this process is the organization, planning and implementation of intervention and improvement measures (UN, 2016). Within disaster management, the process of creating common goals and common values takes an important place (Pearce, 2000).

Disaster management; determination of risky areas and issues; control of natural, technological, social, human, political conditions; ensuring the development of rational plans, policies and methods; it is an interdisciplinary study involving public administration at its center, covering the process from planning to control in management related to the consideration of every detail, raising awareness and adopting it as a culture, including the training of decision-makers and practitioners (Karaman, 2016:3). With this definition, it is emphasized that disaster management is also involved in the field of cultural differences, education and politics, and most importantly, it is an interdisciplinary field. The emphasis on the need for interdisciplinary work in disaster management reveals the importance of concepts such as cooperation and coordination, which is one of the most important problems in this field. Because the ability of different disciplines to work on a similar subject will depend highly on good coordination.

Coordination work means that different elements of a complex structure or activity work together effectively (Lexico, 2020). On the basis of coordination, different institutions have the ability to work together. The process of systematically analyzing a situation, developing relevant information, and determining appropriate command authority using available resources to meet specific goals is another important approach involved in coordination (Blanchard, 2008:169). The intervention in disasters includes a highly complex process in terms of space and timing. This process leads to a more difficult dimension of tasks and responsibilities in a volatile environment. Preparing a coordination strategy in advance for these difficult times both makes the intervention effective and significantly reduces the intervention time (Hashemipour et al., 2017:45). In complex processes resulting from disasters, horizontal communications implemented within institutions often affect coordination more positively than administrative and legal regulations (Drabek, 2007:218). In some studies, it is stated that coordination during disaster and emergency is better applied than the recovery phase after disaster (Moore et al., 2003:316). One more important thing that is necessary for effective coordination is the voluntary and willing participation of stakeholders in the coordination process (Oh \& Lee, 2017:43). Compared to the hierarchical coordination studies; Voluntary and eager studies contribute to coordination studies as it increases social acceptance. Various problems can occur between the institutions involved in disasters. Especially poor planning processes, low economic development and the presence of inadequate logistics infrastructures 


\section{Journal of Pre-Hospital - Hastane Öncesi Dergisi}

JPH, DECEMBER 2021, 6(3):393-406

can pave the way for coordination problems among disaster responding stakeholders (Aldrich, 2019:314).

In disaster management having local authorities strong enough will allow the local need to be met faster and reduce political tension and disputes that may arise between the center and the local (Hermansson, 2019:418). Strengthening local governments in decision-making processes can positively affect coordination efforts in disaster management. Especially in ordinary periods, institutions working in cooperation with local units and institutions implement unexpected coordination work at a more efficient level in the event of a disaster (Morris et al., 2007). Participation of smaller institutions and NGOs in leadership and coordination processes has an important place in order to make coordination work stronger in disaster management (Nolte et al., 2012:725). In addition, active participation of stakeholders and related institutions in interagency communication processes contributes decisively to coordination preparation and coordination in disaster situations (Uddin \& Hossain, 2011:637). Another practice that makes a positive contribution to coordination work during a disaster is that common goals and common principles were established in the pre-disaster period. Defining common principles in the predisaster period allows actors involved in the event of a disaster to benefit more from their areas of expertise (Rey, 2001:116).

In this review it is delineated that Incident Command System (ICS), collaboration, communication, information and resource sharing, common purpose and teamwork, flexibility and authority, and use of social media are at the heart of interagency coordination in disaster management decisively. In order for disaster and emergency situations to be managed in coordination, qualified works should be carried out in the above headings. 
JPH, DECEMBER 2021, 6(3):393-406

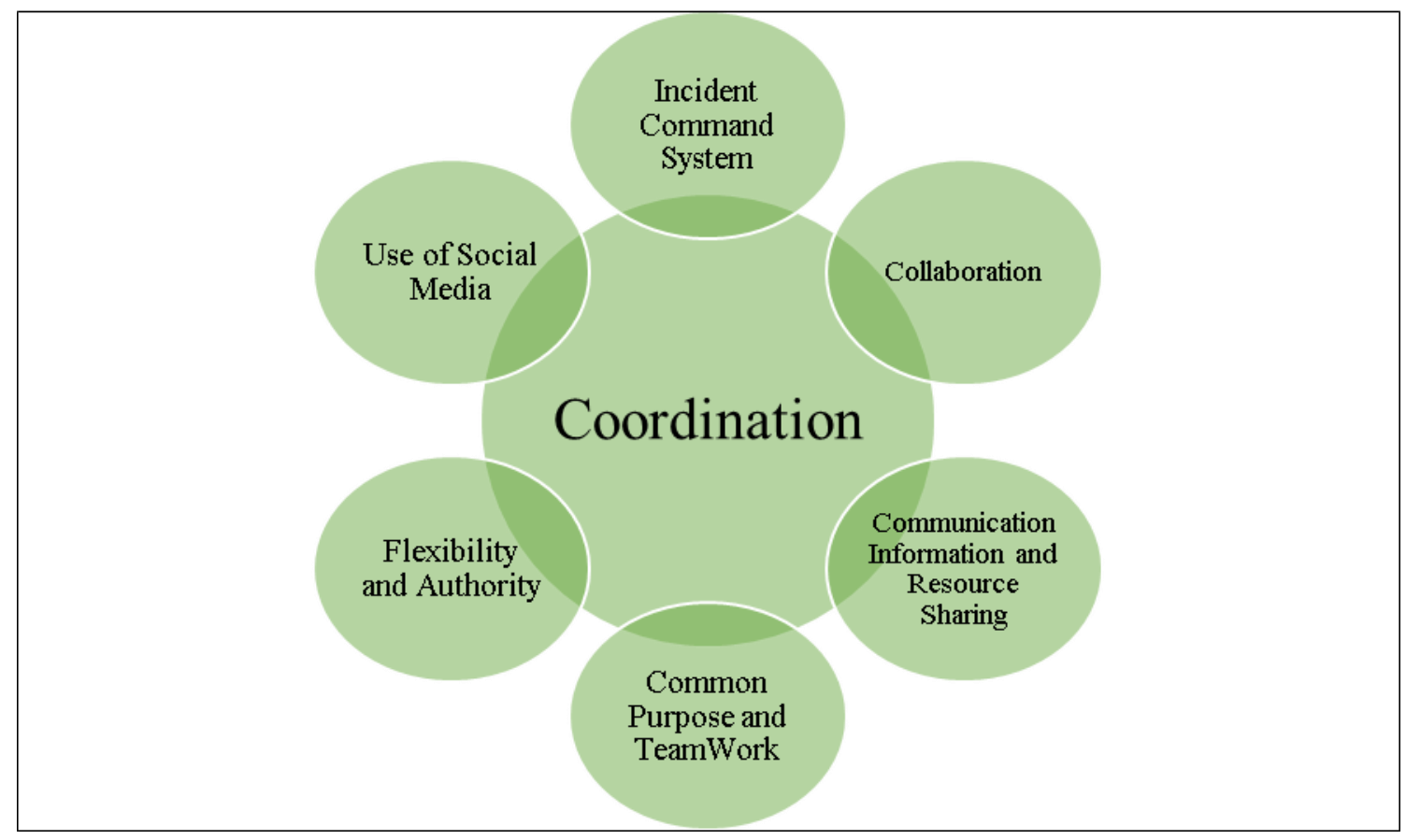

Figure 1: Disaster Management Coordination Components

\section{INCIDENT COMMAND SYSTEM}

Incident Command System (ICS) is a standard approach to command, control and coordination and provides a common hierarchy in which personnel from multiple organizations can be effective (FEMA, 2017:24). ICS first appeared in the 1970s with fire response efforts in the American State of California. A serious fire that hit Southern California in the 1970s has exposed many problems with intergovernmental and multi-agency cooperation and communications. (Coppola, 2007:280). The California government has launched a project called 'California's Potential Emergencies and Fire Fighting Resources' to create a new structure to combat fires and respond to emergencies in the state. This project is called 'FIRESCOPE', short for English words. FIRESCOPE aims to create a system that can respond to all types of incidents, not just wildfires (Chang, 2017:51).

Although multiple institutional disaster response efforts are tried to be managed with various systems, they often bring some setbacks and problems.

Many of these problems;

- Using non-standard terminology between various institutions in the intervention,

- The need to expand and narrow disaster response as required by the situation,

- Presence of non-standard and non-integrated communication,

- Conflicting action plans of different organizations, 
JPH, DECEMBER 2021, 6(3):393-406

- Presence of multiple and often unnecessary facilities,

- Compete or conflict with organizational structures,

- Inconsistent or nonexistent information about disaster,

- Ambiguous authority definitions (Coppola, 2015:374).

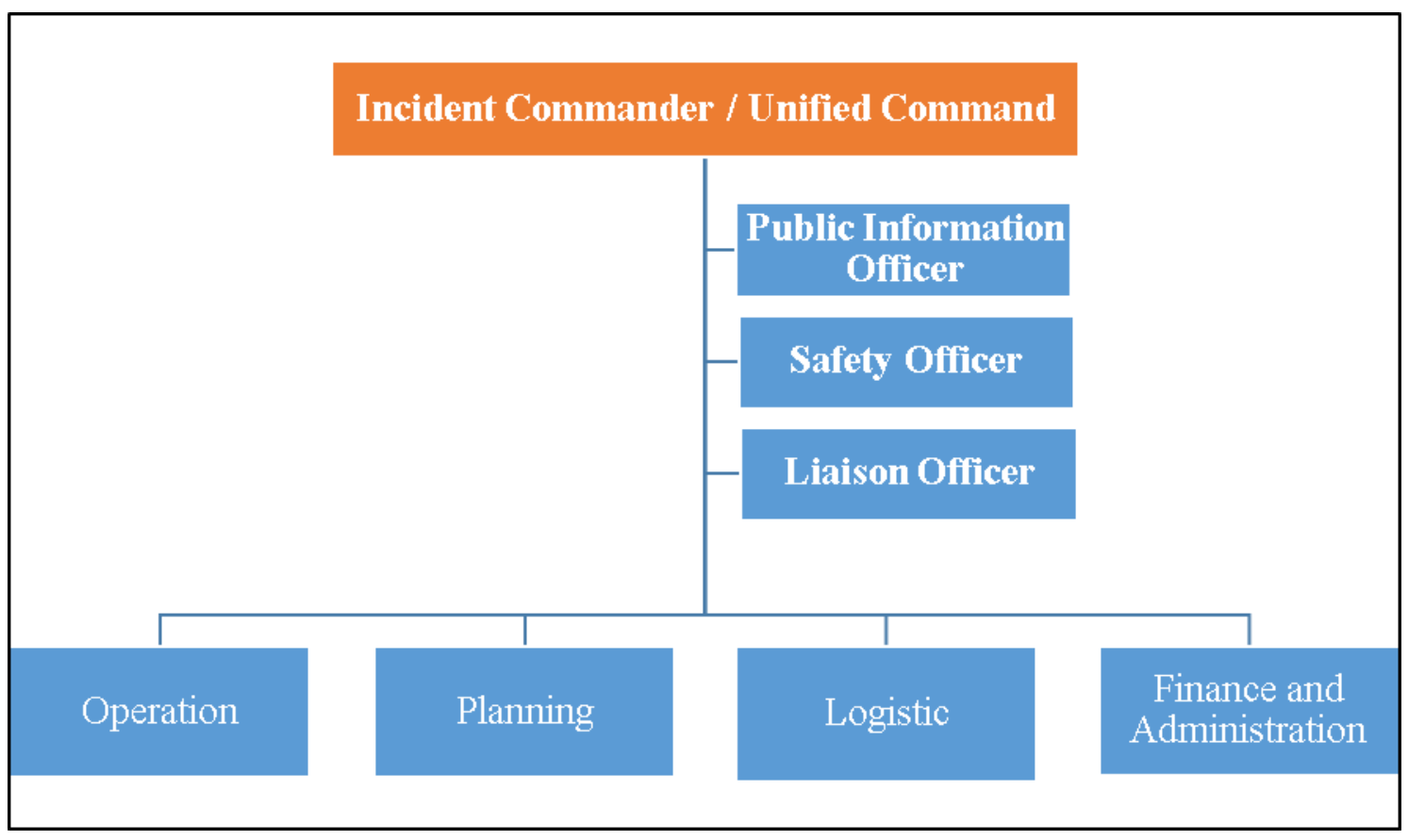

Figure 2: Incident Command System(FEMA, 2017:25)

\section{COLLABORATION}

The concept of collaboration requires working together to achieve a specific goal or result. It seems that the concept of collaboration is used in some cases, instead of coordination. But coordination occurs as a result of regular collaboration activities. Coordination with more explicit expression is an output of collaboration.

Basic features of collaboration;

- Collaboration refers to an activity, not a situation,

- Collaboration focuses on the process of working together,

- Collaboration refers to equal participation in processes,

- Collaboration is a process-oriented approach,

- Collaboration can occur at unexpected times (Carlson, 2014:25).

In order to support coordination, it is expected that controlled interdisciplinary collaboration will occur during the preparation period and spontaneous collaboration will occur during the intervention (Scholtens, 2008:206). Collaboration processes often have various difficulties. In general, these challenges are caused by situations such as perceiving processes 
JPH, DECEMBER 2021, 6(3):393-406

and events differently, willingness, political views and expectations, and seeing disaster management work based on collaboration as unnecessary (Raungratanaamporn et al., 2014: 658). In addition, similar corporate trends make important contributions to in-agency and interagency collaboration (Sapat et al., 2019:12). Collaboration between institutions in disaster management can occur in some cases in the form of resource dependency. Resource-dependent collaboration; it refers to the collaboration of institutions in order to perform their functions in an environment of limited resources (Pfeffer \& Salancik, 2003:258-261).

Resource-dependent collaboration is based on;

- Institutions are affected by external circles and other institutions,

- The success of institutions is uncertain,

- Institutions take actions to manage external interdependencies,

- Institutions tend to look for other organizations that can command relatively more power and resources decisively (Pfeffer, 1997:63).

\section{COMMUNICATION, INFORMATION AND RESOURCE SHARING}

In disaster communication, internet or satellite-based systems, wire or radio systems are mostly used. The basis of communication is that the right information reaches the goal by the right method, at the right time and in continuity. It is especially important to have alternative communication systems in disaster response operations (Aros \& Gibbons, 2018b:78). The involvement of multiple actors in the coordination phase of disasters leads to the emergence of an intensive communication network. This communication network mainly includes special needs, resource inquiry, packaging and logistics preparations, location detection and delivery time. In addition, communication between actors allows the service or product to reach the affected people and those in need faster (Aros \& Gibbons, 2018a:451).

The harmonious operation of communication and information sharing systems with national systems is especially important for search and rescue teams to work in coordination (Garnett \& Kouzmin, 2007:179). In disasters, accurate communication and information sharing occurs from official institutions to citizens. But in the event of a disaster, people often tend to behave like the people around them. It is important to develop horizontal information sharing mechanisms among citizens as well as to improve information sharing from official institutions to citizens (Linardi, 2016:31).

In terms of institutions, the flow of information is examined in five different categories.

These categories are; 
JPH, DECEMBER 2021, 6(3):393-406

- In-institutional information flow,

- Interagency information flow,

- Flow of information from institutions to the public,

- Flow of information from the public to different institutions,

- Information flow between different systems of institutions (Quarantelli, 1988:376).

\section{COMMON PURPOSE AND TEAMWORK}

The common goal of coordination efforts in disasters is mostly to save lives and help people. In order to carry out coordination efforts effectively in disaster management, stakeholders must work for a common purpose and be aware that they are working for a common purpose. Teamwork is generally defined as the collaboration or coordinated work of a group of associated people who work together for a common purpose (Larkin, 2010:497). This coordinated work; in disasters and emergencies, it is carried out by teams whose common purpose is to save lives. In addition, it is very important for teamwork to know the health status of team members and their previous experience before disaster response (Holmgren et al., 2019:829).

Effective teamwork contributes to improving the quality of disaster management through effective coordination and communication with all relevant actors involved in disaster and emergency situations (Selvaraj \& Sandaran, 2019:122). Despite the failures or problems that occur in coordination efforts in disaster management, it is an ethical decency to perform the correct work between teams or within teams, especially in disaster operations (Larkin, 2010: 499). Exercises and trainings are important for developing teamwork in disaster management. In particular, the application of desk exercises and various simulations contribute decisively to the development of inter-professional teamwork (Glauberman et al., 2020:355).

There are several characteristics of effective teamwork.

These features;

- Team success and commitment to shared goals,

- Solidarity,

- Interpersonal skills,

- Open communication and positive feedback,

- Suitable team structure,

- Commitment to team processes, leadership and accountability (Tarricone \& Luca, 2002: 641).

Some communication skills and basic competencies involved in coordination are flexibility, adaptation, personal care, perception of humor, critical thinking, problem solving, 
JPH, DECEMBER 2021, 6(3):393-406

etc. These qualifications are decisively perceived by disaster workers as important on the basis of disaster response and inter-professional teamwork (Peller et al., 2013:397). Following references to the importance of teamwork, as a result, it seems that the essence of real success in disasters is teamwork (Kerfoot, 2019:266).

\section{FLEXIBILITY AND AUTHORITY}

Disaster management requires dealing with predicted and unforeseen changes. Flexibility means being able to cope with such changes by performing various maneuvers according to the nature and time of the event (Duarte et al., 2019:24). In particular, it is important to act flexibly and adapt to conditions in order to cope with external factors and uncontrollable situations that prevent the system from continuing (Morlok \& Chang, 2004: 406). Flexibility in disaster management is a feature of the system that allows pre-planning of how to deal with disasters to minimize negative consequences. This planning refers to actions taken before any disaster, as well as actions intended after a disaster (Morlok \& Chang, 2007:344). Team leaders who use authority should consult the opinions of team members on some issues that require expertise. An expert's opinion may differ from others, which allows for more realistic decisions and for the benefit of the authorities to question expectations and correct if there are inaccuracies (Matori \& Lawal, 2014:717).

Delaying various decisions or making late decisions in disasters, especially under time pressure, can lead to an increase in the loss of life caused by disasters or causes an increase in the extent of the damage caused (Cosgrave, 1996:28). Decision-making skills should be developed theoretically and practically within the use of authority in disaster management. In disasters, some situations occur that negatively affect the ability to make corporate decisions.

These situations;

- Employee depletion from excessive workload,

- Corporate authority confusion,

- Corporate field conflicts,

- Corporate legal differences (Quarantelli, 1988:379).

\section{USE OF SOCIAL MEDIA}

The use of social media in disaster response and coordination processes provides an environment for interaction from the personnel on the ground to the manager in the center (Opdyke \& Javernick-Will, 2014:87). One of the issues to be considered regarding the use of 
JPH, DECEMBER 2021, 6(3):393-406

social media for coordination in disaster management is that the reliable source of the information shared can be confirmed. Because in disaster and emergency situations, some information that is shared instantly may not be confirmed. In such cases, corporate media accounts must be followed and corporate accounts should be considered as reliable sources. In addition, disclosure of accurate information in disaster management to the public by representatives of institutions as soon as possible is called the golden rule of disaster communication (Lee, 2008:390). Also, cooperation with social media users and media organizations also positively affects coordination efforts in disaster management (Prizzia, 2008:94).

Social media has various application areas in almost all of the disaster management stages. Social media can be used effectively at all stages; information dissemination, disaster planning and training, collaborative problem solving and decision making and information collection (Chan, 2020). All social media contents are not content that requires intervention. It seems that social media users are more interested in informative content, especially in disaster response processes, than in content that requires intervention and implementation (Yan \& Pedraza-Martinez, 2019). This suggests that in disaster management, social media users will mostly be people who share information, not just people who land on the field.

\section{CONCLUSION}

Disaster and emergencies include complex processes that require different institutions and organizations together in line with a common purpose. Although this common purpose changes according to the nature of the events, it is often realized as to save human life and prevent physical losses. In order to carry out these common objectives in disasters, move of the relevant institutions and organizations in coordination are becoming an imperativeness. In case of disasters, the full implementation of interagency coordination studies depends decisively on some sub-titles in coordination. These sub-headings are Incident Command System (ICS), collaboration, communication, information and resource sharing, common purpose and teamwork, flexibility and authority, and use of social media. ICS is a standard approach to command, control and coordination of management that takes place at the scene and provides a common hierarchy in which personnel from multiple organizations can be effective. Collaboration requires working together to achieve a specific goal. Coordination occurs as a result of regular collaboration activities. Communication, information and resource sharing covers the main area of work, especially for the Coordination of operational processes. Common goal and teamwork contribute to directing the efforts of different institutions and 
JPH, DECEMBER 2021, 6(3):393-406

organizations towards the determined goal. Flexibility and authority are an important title for rapid adaptation to changing conditions. The use of social media is an important area that supports coordination efforts. As conclusion in order to establish a qualified interagency coordination in disaster management, complete and accurate work must be carried out in the above-mentioned areas.

\section{References}

AFAD. (2014). Açıklamalı Afet Yönetimi Terimleri Sözlüğü. https://www.afad.gov.tr/aciklamali-afetyonetimi-terimleri-sozlugu, 09.01.2021.

Aldrich, DP. (2019). Challenges to Coordination: Understanding Intergovernmental Friction During Disasters. International Journal of Disaster Risk Science, 10(3), 306-316. https://doi.org/10.1007/s13753-019-00225-1

Aros, SK., \& Gibbons, DE. (2018a). Exploring communication media options in an inter-organizational disaster response coordination network using agent-based simulation. European Journal of Operational Research, 269(2), 451-465. https://doi.org/10.1016/j.ejor.2018.02.013

Aros, SK. \& Gibbons, DE. (2018b). Developing an agent-based simulation model of the use of different communication technologies in inter-organizational disaster response coordination. Proceedings of the 2018 Winter Simulation Conference, 68-79. https://doi.org/10.1109/WSC.2018.8632257

Blanchard, BW. (2008). Guide To Emergency Management and Related Terms, Definitions, Concepts, Acronyms, Organizations, Programs, Guidance, Executive Orders \& Legislation. In Federal Emergency Management Agency. https://doi.org/10.1017/CBO9781107415324.004

Carlson, EJ. (2014). Collaboration and Confrontation in Interorganizational Coordination: Preparing to Respond to Disasters [University of Illinois]. https://core.ac.uk/download/pdf/29152989.pdf

Carr, LJ. (1932). Disaster and the Sequence-Pattern Concept of Social Change. American Journal of Sociology, 38(2), 207-218. https://doi.org/10.1086/216030

Chan, JC. (2020). The Role of Social Media in Crisis Preparedness, Response and Recovery. Oecd. https://www.oecd.org/governance/risk/The role of Social media in crisis preparedness, response and recovery.pdf, 09.01.2021.

Chang, HH. (2017). A literature review and analysis of the incident command system. International Journal of Emergency Management, 13(1), 50-67. https://doi.org/10.1504/IJEM.2017.081193

Coppola, DP. (2007). Introduction to International Disaster Management (M. Listewnik (ed.); First). Elsevier Inc.

Coppola, DP. (2015). Introduction to International Disaster Management. In Introduction to International Disaster Management. https://doi.org/10.1016/C2009-0-64027-7 


\section{Journal of Pre-Hospital - Hastane Öncesi Dergisi}

JPH, DECEMBER 2021, 6(3):393-406

Cosgrave, J. (1996). Decision making in emergencies. Disaster Prevention and Management: An International Journal, 5(4), 28-35. https://doi.org/https://doi.org/10.1108/09653569610127424

Drabek, TE. (2007). Community Processes: Coordination. In H. Rodriguez, E. L. Quarantelli, \& R. R. Dynes (Eds.), Handbook of Disaster Research (pp. 217-233). Springer Science+Business Media, LLC.

Duarte, R., Gorte, L., \& Deschamps, F. (2019). Flexibility Practices in Disaster Response-A Process Approach Based Evaluation. In Springer Proceedings in Mathematics and Statistics (Vol. 281). Springer International Publishing. https://doi.org/10.1007/978-3-030-14973-4_3

FEMA. (2017). National Incident Management System. https://www.fema.gov/sites/default/files/202007/fema_nims_doctrine-2017.pdf, 09.01.2021.

Garnett, JL., \& Kouzmin, A. (2007). Communicating throughout Katrina: Competing and Complementary Conceptual Lenses on Crisis Communication. Public Administration Review, 67(1), 171188. https://doi.org/https://doi.org/10.1111/j.1540-6210.2007.00826.X

Glauberman, GHR., Wong, LCK., Bray, ML., \& Katz, AR. (2020). Disaster Aftermath Interprofessional Simulation: Promoting Nursing Students' Preparedness for Interprofessional Teamwork. Journal of Nursing Education, 59(6), 353-356. https://doi.org/10.3928/01484834-20200520-11

Hashemipour, M., Stuban, S., \& Dever, JR. (2017). A community-based disaster coordination framework for effective disaster preparedness and response. Australian Journal of Emergency Management, 32(2), 41-46. https://ajem.infoservices.com.au/items/AJEM-32-02-18, 09.01.2021.

Hermansson, H. (2019). Challenges to Decentralization of Disaster Management in Turkey : The Role of Political- Administrative Context. International Journal of Public Administration, 42(5), 417-431. https://doi.org/10.1080/01900692.2018.1466898

Holmgren, J., Paillard-Borg, S., Saaristo, P., \& Strauss, E. von. (2019). Nurses' experiences of health concerns, teamwork, leadership and knowledge transfer during an Ebola outbreak in West Africa. Nursing Open, 6, 824-833. https://doi.org/10.1002/nop2.258

Karaman, ZT. (2016). Afet Yönetimine Giriş ve Türkiye'de Örgütlenme. In Z. T. KARAMAN \& A. ALTAY (Eds.), Bütünleşik Afet Yönetimi (1st ed., pp. 1-38). Birleşik Matbaacılık.

Kerfoot, KM. (2019). Chaos, Teamwork, Compassion, and Leadership: Disasters and Nursing’s Finest Hours. Nursing Economic The Journal for Health Care Leaders, 37(5), 265-267. http://www.nursingeconomics.net/necfiles/2019/SO19/265.pdf

Larkin, GL. (2010). Unwitting Partners in Death: The Ethics of Teamwork in Disaster Management. American Medical Association Journal of Ethics, 12(6), 495-501. https://journalofethics.amaassn.org/sites/journalofethics.ama-assn.org/files/2018-06/oped1-1006.pdf, 09.01.2021.

Lee, M. (2008). Media Relations and External Communications during a Disaster. In J. Pinkowski (Ed.), Disaster Management Handbook (pp. 387-399). CRC Press. 


\section{Journal of Pre-Hospital - Hastane Öncesi Dergisi}

JPH, DECEMBER 2021, 6(3):393-406

Lexico. (2020). Coordination. https://www.lexico.com/definition/coordination, 09.01.2021.

Linardi, S. (2016). Peer coordination and communication following disaster warnings : An experimental framework. Safety Science, 90, 24-32. https://doi.org/10.1016/j.ssci.2016.03.017

Matori, AN., \& Lawal, DU. (2014). Flood Disaster Forecasting: A GIS-based Group Analytic Hierarchy

Process Approach. Applied Mechanics and Materials, 567, 717-723. https://doi.org/10.4028/www.scientific.net/AMM.567.717

Moore, S., Daniel, M., \& Eng, E. (2003). International NGOs and the Role of Network Centrality in Humanitarian Aid Operations: A Case Study of Coordination During the 2000 Mozambique Floods. Disasters, 27(4), 305-318.

Morlok, EK., \& Chang, DJ. (2004). Measuring capacity flexibility of a transportation system. Transportation Research Part A: Policy and Practice, 38(6), 405-420. https://doi.org/10.1016/j.tra.2004.03.001

Morlok, EK., \& Chang, DJ. (2007). Disaster and degradation management: relevance of the concept of flexibility. International Journal of Critical Infrastructures, 3(3/4), 327-345.

Morris, JC., Morris, E. D., \& Jones, DM. (2007). Reaching for the Philosopher's Stone: Contingent Coordination and the Military's Response to Hurricane Katrina. Public Administration Review, 67(1), 64106. https://doi.org/https://doi.org/10.1111/j.1540-6210.2007.00818.x

Nolte, IM., Martin, EC., \& Boenigk, S. (2012). Cross-Sectoral Coordination of Disaster Relief. Public Management Review, 14(6), 707-731. https://doi.org/doi.org/10.1080/14719037.2011.642629

O’Keefe, P., Westgate, K., \& Wisner, B. (1976). Taking the Naturalness Out of Natural Disasters. Nature, $260,566-567$.

Oh, N., \& Lee, J. (2017). Activation and variation of the United Nation's cluster coordination model : a comparative analysis of the Haiti and Japan disasters. Journal of Risk Research, 20(1), 41-60. https://doi.org/https://doi.org/10.1080/13669877.2015.1017826

Opdyke, A., \& Javernick-Will, A. (2014). Building Coordination Capacity: Post-Disaster Organizational Twitter Networks. Proceedings of the 4th IEEE Global Humanitarian Technology Conference, GHTC 2014, 86-92. https://doi.org/10.1109/GHTC.2014.6970265

Pearce, L. (2000). An Integrated Approach For Community Hazard, Impact, Risk and Vulnerability Analysis. University of British Columbia.

Peller, J., Schwartz, B., \& Kitto, S. (2013). Nonclinical Core Competencies and Effects of Interprofessional Teamwork in Disaster and Emergency Response Training and Practice: A Pilot Study. Disaster Medicine and Public Health Preparedness, 7(4), 395-402. https://doi.org/10.1017/dmp.2013.39

Pfeffer, J. (1997). New Directions for Organization Theory: Problems and Prospects. Oxford University Press. 


\section{Journal of Pre-Hospital - Hastane Öncesi Dergisi}

JPH, DECEMBER 2021, 6(3):393-406

Pfeffer, J., \& Salancik, GR. (2003). The External Control of Organizations: A Resource Dependence Approach. In Stanford Business Classics. Stanford University Press.

Prizzia, R. (2008). The Role of Coordination in Disaster Management. In J. Pinkowski (Ed.), Disaster Management Handbook (pp. 75-98). CRC Press.

Quarantelli, EL. (1988). Disaster Crisis Management: A Summary of Research Findings. Journal of Management Studies, 25(4), 373-385. https://doi.org/10.1111/j.1467-6486.1988.tb00043.x

Raungratanaamporn, I., Pakdeeburee, P., Kamiko, A., \& Denpaiboon, C. (2014). Governmentcommunities Collaboration in Disaster Management Activity: Investigation in the Current Flood Disaster Management Policy in Thailand. Procedia Environmental Sciences, 20, 658-667. https://doi.org/10.1016/j.proenv.2014.03.079

Rey, F. (2001). The Complex Nature of Actors in Humanitarian Action and the Challenge of Coordination. In The Humanitarian Studies Unit (Ed.), Reflections on Humanitarian Action (pp. 99-119). Pluto Press.

Sapat, A., Esnard, AM., \& Kolpakov, A. (2019). Understanding Collaboration in Disaster Assistance Networks: Organizational Homophily or Resource Dependency? American Review of Public Administration, 49(8), 957-972. https://doi.org/10.1177/0275074019861347

Scholtens, A. (2008). Controlled Collaboration in Disaster and Crisis Management in the Netherlands, History and Practice of an Overestimated and Underestimated Concept. Journal of Contingencies and Crisis Management, 16(4), 195-208.

Selvaraj, S., \& Sandaran, SC. (2019). Discourses of Flood Disaster Preparedness by NGOs: Humanitarian Aid, Teamwork and Victimization. GEMA Online Journal of Language Studies, 19(4), 111-127. https://doi.org/10.17576/gema-2019-1904-06

Tarricone, P., \& Luca, J. (2002). Successful teamwork: A case study. 25th HERDSA Annual Conference, 640-646. https://ro.ecu.edu.au/cgi/viewcontent.cgi?article=5007\&context=ecuworks, 09.01 .2021

Uddin, S., \& Hossain, L. (2011). Disaster coordination preparedness of soft-target organisations. Disasters, 35(3), 623-638. https://doi.org/doi:10.1111/j.1467-7717.2011.01229.x

UN. (2016). Report of the open-ended intergovernmental expert working group on indicators and terminology relating to disaster risk reduction (Vol. 21184, Issue December). https://www.preventionweb.net/files/50683_oiewgreportenglish.pdf , 09.01.2021.

$\begin{array}{llllll}\text { UNISDR. (2009). Terminology on } & \text { Disaster Risk Reduction. }\end{array}$ https://www.unisdr.org/files/7817_UNISDRTerminologyEnglish.pdf, 09.01.2021.

WHO. (1998). Emergency Health Training Programme Trainers' Guide (Issue July 1998).

Yan, L., \& Pedraza-Martinez, A J. (2019). Social Media for Disaster Management: Operational Value of the Social Conversation. Production and Operations Management, 28(10), 2514-2532. 